\title{
A Prospective Study of Various Flaps in Compound Electrical Burn Defects in a Tertiary Care Centre
}

\author{
L. Murali ${ }^{1}$, Y. Kavitha ${ }^{2}$ \\ ${ }^{1}$ Assistant Professor, Department of Community Medicine, Kakatiya Medical College/MGM Hospital, Warangal, \\ Telangana, India. ${ }^{2}$ Assistant Professor, Department of Plastic Surgery, Kakatiya Medical College/MGM Hospital, \\ Warangal, Telangana, India.
}

\section{ABSTRACT}

\section{BACKGROUND}

Electrical burns are uncommon. They result in high morbidity and mortality due to severe tissue damage. We wanted to analyse epidemiological variables of electrical injuries, identify preventable measures, study the various post electrical burn compound defects/wounds and the addressal of them, study the various flaps used for coverage of various post electrical burns defects and to analyse the outcome of flap cover of compound electrical burns defects.

\section{METHODS}

This is a prospective observational study of various flaps for compound defects in patients with electrical burns conducted in a tertiary care centre. A total of sixty-five flaps was performed for reconstruction of various defects in forty-eight patients of electrical burns in Burns Unit, Department of Plastic Surgery, MGM Hospital, Warangal, from July 2018 to March 2019.

\section{RESULTS}

Mean age was 27.83 years. $91.67 \%$ ( 44 out of 48 ) patients were male, only 4 patients out of 48 were female. In this study, $93.75 \%$ ( 45 out of 48 ) patients had high voltage electricity injuries. Only $6.25 \%$ (3 out of 48 ) had low voltage electricity injuries. In this study $95.38 \%$ (62 flaps) were done delayed duration, $4.62 \%$ (3 flaps) done early flap coverage. For defects over forearm and wrist, most commonly used flaps were superiorly based fasciocutaneous flaps and paraumbilical flaps equally with 29.73\% each. Most common flap for scalp defects were transposition flaps $72.73 \%$, for shoulder reconstruction was trapezius musculocutaneous flap (100\%), leg and for ankle was reverse sural artery flap $66.67 \%$.

\section{CONCLUSIONS}

Majority of the study population was male $91.67 \%$ while $8.33 \%$ was female. The age of patients ranged between 9 to 60 years, with 21-30 years being the most common affected age group. Most of the patients with defect underwent delayed flap cover $(95.38 \%)$ while $4.62 \%$ underwent early flap coverage. Most common site involved in electrical burns was forearm and wrist (45.90\%). For defects over forearm and wrist, most commonly used flaps were superiorly based fasciocutaneous flaps and paraumbilical flaps equally with $29.73 \%$ each.

\section{KEY WORDS}

Electrical Burn Injuries, High Voltage Injuries, Low Voltage Injuries
Corresponding Author:

Dr. Y. Kavitha,

Assistant Professor,

Department of Plastic Surgery,

H. No. 3-1-307/3, Vishista Apartment,

Kakatiya Colony, Warangal Urban-506011,

Telangana, India.

E-mail: kavilingala@gmail.com

DOI: $10.14260 / j e m d s / 2019 / 619$

Financial or Other Competing Interests: None.

How to Cite This Article:

Murali L, Kavitha Y. A prospective study of various flaps in compound electrical burn defects in a tertiary care centre. J. Evolution Med. Dent. Sci. 2019;8(37): 2850-2855, DOI:

$10.14260 / j e m d s / 2019 / 619$

Submission 20-06-2019,

Peer Review 01-09-2019,

Acceptance 09-09-2019,

Published 16-09-2019. 


\section{BACKGROUND}

Electrical burns are uncommon. They result in high morbidity and mortality due to severe tissue damage.(1). In India, electrical burns are the second commonest type of burns and amount to $14 \%$ after the flame burns. Involvement of the limbs leading to amputation is quite common especially these burns happen work related events or due to accidental contact.(2) The wounds are potentially life threatening and sometimes cause a major handicap to the patient.(3) The decision on which method of wound closure should be used depends entirely on the geometry of the wound and on the local wound factors. ${ }^{(4)}$ The main indications for flap covers are exposed vital structures such as bone, tendon and nerve, a need for stable flap cover and future surgeries for restoration of function in that affected part.

We wanted to study the various post electrical burn compound defects/wounds, study the various flaps used for covering them and analyse the outcome of these flap covers.

\section{METHODS}

The study protocol was approved by institutional ethics committee. This is a prospective observational study of various flaps for compound defects in patients with electrical burns in a tertiary care centre. A total of sixty-five flaps were performed for reconstruction of various defects in forty-eight patients of electrical burns in Burns unit, Department of plastic surgery, MGM hospital, Warangal, from July 2018 to March 2019 were prospectively analysed.

\section{Exclusion Criteria}

- Patients of $<5$ years of age and $>60$ years of age.

- Patients with significant medical disorders and unfit for surgical procedures.

- Patients who had head injury and fractures of extremities.

- Patients managed conservatively, with skin grafting.

- Patients not giving consent for flap cover.

During initial evaluation at emergency, reliable vascular access, urinary catheterization, cardiac monitoring, advanced trauma life support algorithm were applied to all patients. Patients with history of fall from height were examined for accompanying injuries further examinations and treatments were performed on these patients, as necessary. After the initial intervention, fluid resuscitation was started, according to the parkland formula, to replace fluid loss and prevent hypovolemic shock. The patients were then transported to the burn unit. Urgent fasciotomy/Escharectomy (F/E) was performed for the existence or suspicion of a compartment syndrome. Debridement was performed when necessary. We protected vital structures, such as tendons, vessels, nerves, bones and joints during debridement.

In electrical burns, tissue injury is the result of a change from electric energy to thermal energy. In terms of resistance, the skin provides intermediate resistance and is an important factor for impeding current flow. Nerve tissue is the least resistant, and together with the vessels, muscles, and mucous membranes, it offers a path of low resistance for electricity. Remnants of the current can cause thermal injury to the muscle, fat tissue, and skin as it moves to an exit site. The skin at entry and exit areas is usually blackened by the electrical current, which can also damage internal structures, such as tendons, nerves or vessels. Therefore, although the treatment of burn injury has advanced with time, electrical burn patients still face treatment difficulties, as the visible areas of necrosis represent only a small part of the tissues that are actually damaged. The arc from the electric potential difference can quickly damage muscle. The arc is an intense flame composed of ionized particles with heat of approximately $3000{ }^{\circ} \mathrm{C}-20,000{ }^{\circ} \mathrm{C}$. It can jump over $2-3 \mathrm{~cm}$ per $1000 \mathrm{~V}$, and the human body can be damaged without direct contact with the live wire. The result is the typical ovalshaped burn wound frequently observed on the wrist, elbow, or axilla. In addition to the direct damage in high-tension electrical injuries; gradual ischemia is also a serious problem. Thrombus formation at the small artery or arteriole, vessel constriction slowing the blood flow, and tissue necrosis can occur. These are contributing factors influencing the decision of amputation. One of the best methods to protect the viable tissue in the initial stage of treatment is early decompression with a fasciotomy of the injured compartment. If initial management is completed; the surgeon can consider the next stage of reconstruction. Simple surgical procedures, such as skin grafts or artificial dermis, are useful at first, and regional or free flaps are useful if the injury is severe. Reconstruction other than skin grafts is divided into three categories: local flaps, regional flaps, distant flaps and free flaps. Local, regional, distant flaps are primarily used to correct small defects, but free flaps were also used for wide and complex defects. Latissimus dorsi free flaps were the most commonly used, followed by anterolateral thigh free flaps and other types of free flaps. Small defects in the extremities can be reconstructed with local or distant flaps, such as cross-finger flaps or groin flaps. However, free flaps were inevitable in severe and complex defects with deep structure exposure. Moderately sized defects are typically treated with radial forearm flaps or anterolateral thigh free flaps. Latissimus dorsi flaps are primarily used for extensive defects that are greater than the size of one hand. Therefore, when performing flap surgery must consider many factors, such as the patient's general condition, donor site condition, surgeon's expertise [skill level], flap character, vessel condition, and possibility of early excision. In critical situations, such as inhalation burns or septic conditions, reconstructive surgical management cannot be started, because life-saving surgical management, such as an allograft, is typically performed beforehand. Therefore, many hightension electrical injury patients often do not have the chance to receive an operation to recover function of the affected extremity immediately. Amputations were performed from the distal level (if possible) to conserve functionality. Lesions not necessitating amputations were closed with reliable and proper flaps soon after debridement.

Age, Gender distribution, Site, Size of defect and structures damaged, Timing of the flap cover (Early: $<7$ days from date of injury or Delayed), Type and dimensions of the flap, Complications if any were studied. 


\section{RESULTS}

In the present study, most common age group affected with electrical burn injuries was 21-30 years (41.67\%) followed by $11-20$ years $(22.92 \%)$, only two patients below the age 10 years (4.16\%). Mean age was 27.83 years. Youngest patient with 9 years and oldest patient with 60 years. In this study 91.67\% (44 out of 48) patients were male, only 4 patients out of 48 were female. This might be because males are predominately the major workforce in farming, industries, construction sites and other occupations. In this study 93.75\% (45 out of 48) patients had high voltage electricity injuries. Only $6.25 \%$ (3 out of 48) had low voltage electricity injuries. In this study $95.38 \%$ (62 flaps) were done delayed duration, $4.62 \%$ (3 flaps) done early flap coverage.

During this study it was observed that some patients had more than one site with compound defects. Most common site involved in was forearm and wrist comprised $45.90 \%$ (28 defects out of 61). Next common site was scalp 18.03\% (11 defects out of 61).Followed by leg and ankle which were $9.84 \%$ ( 6 defects out of 61 ).

The most common flap for scalp defects were transposition flaps $72.73 \%$ (8 out of 11 flaps).Followed by Rotation flap, bipedicled flap, Trapezius musculocutaneous flap each of $9.09 \%$ respectively. A total of seven patients had electrical burn compound defects over face. These were reconstructed with flap covers. Out of that one defect over forehead covered with rotation flap. One defect of lower eye lid reconstructed with Fricke's flap. Two defects of nose reconstructed with median forehead flap. One defect of upper lip reconstructed with extracorporeal radial artery forearm flap. One defect of lower lip reconstructed with deltopectoral flap. One defect of mandible reconstructed initially with trapezius musculocutaneous flap which got necrosed in critical area of flap then forehead flap was used to cover the critical area, this forehead flap also necrosed, then pectoralis major musculocutaneous flap used, it also got necrosed, then extra corporeal radial artery forearm flap was used along with tongue flap to cover intra oral aspect of mandible. It settled well without any complication.

The most commonly used flap for shoulder reconstruction was Trapezius musculocutaneous flap. For defect over axilla Latissimus dorsi flap was used. For defects over forearm and wrist most commonly used flaps were superiorly based fasciocutaneous flaps and Paraumbilical flaps with $29.73 \%$ (11 flaps out of 37), inferiorly based fasciocutaneous flaps $13.51 \%$ (5 out of 37 ) and groin flap 2.70\% (1 out of 37).For defects over dorsum of hand groin flaps were used in 8.11\%(3 out 37), For defects over fingers Louvre flap was used in $5.40 \%$ (2 out of 37), Superiorly based fasciocutaneous flap in $2.70 \%$ (1 out of 37). The most commonly used flap for leg and ankle was Reverse sural artery flap $66.67 \%$ ( 4 out of 6 flaps) followed by Cross leg flap and inferiorly based medial fasciocutaneous flap with $16.67 \%$ each. The most commonly used type of flaps was fasciocutaneous flaps $89.23 \%$, musculocutaneous flaps were $9.23 \%$, muscle flaps were $1.54 \%$.

The most common complication was marginal necrosis occurred in $15.38 \%$ flaps (10 out of 65 flaps) followed by dehiscence of flap in $12.31 \%$ (8 out of 65 flaps ) graft loss occurred in $4.62 \%$ flaps( 3 out of 65 ), hematoma and total flap necrosis occurred in $3.08 \%$ flaps respectively.

The most common defect size was $>10 \mathrm{cms}$ in $29.51 \%$ defects (18 out of 61 ) followed by $6-8 \mathrm{cms}$ defects comprising of $27.87 \%$ (17 out of 61 ) defects, defects of size $8-10 \mathrm{cms}$ comprising of $22.95 \%$ (14 out of 61 ) defects. The most common dimension of flaps was in the range of $12-15 \mathrm{cms}$ (30 flaps), followed by 6-9 cms (15 flaps), 9-12 cms (13 flaps).

\begin{tabular}{|c|c|}
\hline Anatomic Region \& Site of Defect & Percentage \\
\hline Head and Neck & $11(18.03 \%)$ \\
\hline Scalp & $1(1.64 \%)$ \\
\hline Forehead & $1(1.64 \%)$ \\
\hline Lower eyelid & $2(3.28 \%)$ \\
\hline Nose & $1(1.64 \%)$ \\
\hline Upper lip & $1(1.64 \%)$ \\
\hline Lower lip & $1(1.64 \%)$ \\
\hline Mandible & $2(3.28 \%)$ \\
\hline Upper limb & $1(1.64 \%)$ \\
\hline Shoulder & $28(45.9 \%)$ \\
\hline Axilla & $3(4.92 \%)$ \\
\hline Forearm and & $3(4.92 \%)$ \\
\hline Wrist & $6(9.84 \%)$ \\
\hline Hand & $61(100 \%)$ \\
\hline Fingers & \\
\hline Lower limb & \\
\hline Total & \\
\hline Table 1. Site of Defect \\
\hline
\end{tabular}

\begin{tabular}{|c|c|}
\hline Type of Flap & No. of Flaps Percentage \\
\hline Transposition flap & $8(72.73 \%)$ \\
\hline Rotation flap & $1(9.09 \%)$ \\
\hline Bipedicled flap & $1(9.09 \%)$ \\
\hline Musculocutaneous Flap & $1(9.09 \%)$ \\
\hline Total & $11(100 \%)$ \\
\hline \multicolumn{2}{|c|}{ Table 2. Flaps for Scalp Defects } \\
\hline
\end{tabular}

\begin{tabular}{|c|c|c|}
\hline Site & Flap & No. \& Percentage \\
\hline Forehead & Rotation flap & $1(14.28 \%)$ \\
\hline Lower eye lid & Fricke's flap & $1(14.28 \%)$ \\
\hline Nose & Median forehead flap & $2(28.57 \%)$ \\
\hline Upper lip & Radial artery forearm pedicled flap & $1(14.28 \%)$ \\
\hline Lower lip & Deltopectoral flap & $1(14.28 \%)$ \\
\hline Mandible & Radial artery forearm pedicled flap & $1(14.28 \%)$ \\
\hline Total & \multicolumn{3}{|c|}{ Table 3. Flaps for Defects of Face } \\
\hline \multicolumn{3}{|c|}{} \\
\hline
\end{tabular}

\begin{tabular}{|c|c|c|}
\hline & Flap & No. \& Percentage \\
\hline Shoulder & Trapezius myocutaneous flap & $2(5.40 \%)$ \\
\hline Axilla & Latissimus dorsi myocutaneous flap & $1(2.70 \%)$ \\
\hline \multirow{3}{*}{ Forearm } & Superiorly based abdominal flap & $11(29.73 \%)$ \\
\cline { 2 - 3 } & Inferiorly based abdominal flap & $5(13.51 \%)$ \\
\cline { 2 - 3 } & Paraumbilical flap & $11(29.73 \%)$ \\
\cline { 2 - 3 } & Groin flap & $1(2.70 \%)$ \\
\hline Hand & Groin flap & $3(8.11 \%)$ \\
\hline Fingers & Louvre flap & $2(5.40 \%)$ \\
\hline & Superiorly based abdominal flap & $1(2.70 \%)$ \\
\hline Total & \multicolumn{2}{|c|}{ Table 4. Flaps for Upper Limb Defects } \\
\hline \multicolumn{3}{|c|}{} \\
\hline \multicolumn{2}{|c|}{} \\
\cline { 2 - 3 }
\end{tabular}

\begin{tabular}{|c|c|c|}
\hline Site & Flap & No. \& Percentage \\
\hline \multirow{2}{*}{$\begin{array}{c}\text { Leg and } \\
\text { Ankle }\end{array}$} & Reverse sural artery flap & $4(66.67 \%)$ \\
\cline { 2 - 3 } & Inferiorly based medial fascio cutaneous flap & $1(16.67 \%)$ \\
\cline { 2 - 3 } Total & Cross leg flap & $1(16.67 \%)$ \\
\hline \multicolumn{2}{|c|}{ Table 5. Flaps for Lower Limb Defects } \\
\hline
\end{tabular}




\begin{tabular}{|c|c|}
\hline Type of Flap & No. \& Percentage \\
\hline Fasciocutaneous flaps & $58(89.23 \%)$ \\
\hline Musculocutaneous flaps & $6(9.23 \%)$ \\
\hline Muscle flaps & $1(1.54 \%)$ \\
\hline Free flaps & 0 \\
\hline Total & $\mathbf{6 5 ( 1 0 0 \% )}$ \\
\hline \multicolumn{2}{|c|}{ Table 6. Type of Flap } \\
\hline
\end{tabular}

\begin{tabular}{|c|c|}
\hline Complications & No. \& Percentage \\
\hline Marginal Necrosis & $10(15.38 \%)$ \\
\hline Total Flap Necrosis & $2(3.08 \%)$ \\
\hline Dehiscence & $8(12.31 \%)$ \\
\hline Hematoma & $2(3.08 \%)$ \\
\hline Graft loss & $3(4.62 \%)$ \\
\hline Total & $\mathbf{2 5 ( 3 8 . 4 6 \% )}$ \\
\hline \multicolumn{2}{|c|}{ Table 7. Incidence of Complications } \\
\hline
\end{tabular}

\begin{tabular}{|c|c|c|c|c|c|}
\hline $\begin{array}{c}\text { Size of } \\
\text { Defect }\end{array}$ & Scalp & Face & $\begin{array}{c}\text { Upper } \\
\text { Limb }\end{array}$ & $\begin{array}{c}\text { Lower } \\
\text { Limb }\end{array}$ & $\begin{array}{c}\text { Grand } \\
\text { Total }\end{array}$ \\
\hline$<4 \mathrm{~cm}$ & & 2 & 5 & & 7 \\
\hline $4-6 \mathrm{~cm}$ & 1 & 2 & 2 & & 5 \\
\hline $6-8 \mathrm{~cm}$ & 4 & 2 & 9 & 2 & 17 \\
\hline $8-10 \mathrm{~cm}$ & 6 & 1 & 5 & 2 & 14 \\
\hline$>10 \mathrm{~cm}$ & & & 16 & 2 & 18 \\
\hline Total & $\mathbf{1 1}$ & $\mathbf{7}$ & $\mathbf{3 7}$ & $\mathbf{6}$ & $\mathbf{6 1}$ \\
\hline \multicolumn{7}{|c|}{ Table 8. Size of Defects } \\
\hline
\end{tabular}



\begin{tabular}{|c|c|c|c|c|c|}
\hline Size of Flap & Scalp & Face & Upper Limb & Lower Limb & Total \\
\hline$<3 \mathrm{~cm}$ & 0 & 1 & 2 & 0 & 3 \\
\hline $3-6 \mathrm{~cm}$ & 0 & 0 & 4 & 0 & 4 \\
\hline $6-9 \mathrm{~cm}$ & 3 & 3 & 9 & 0 & 15 \\
\hline $9-12 \mathrm{~cm}$ & 4 & 1 & 8 & 0 & 13 \\
\hline $12-15 \mathrm{~cm}$ & 4 & 6 & 14 & 6 & 30 \\
\hline Total & $\mathbf{1 1}$ & $\mathbf{1 1}$ & $\mathbf{3 7}$ & $\mathbf{6}$ & $\mathbf{8 5}$ \\
\hline \multicolumn{7}{|c|}{ Table 9. Flap Dimensions } \\
\hline
\end{tabular}

\section{DISCUSSION}

The anatomical regions that were reconstructed categorized as head and neck (18 defects, 22 flaps), upper extremity (37 defects, 37 flaps) and lower extremity ( 6 defects, 6 flaps). The patients were analysed based on gender, age, length of hospital stay, accompanying traumas, flap types, complications, and the variables are discussed according to the anatomical region of the injury.

In this study low voltage electrical burn injuries accounts for $6.25 \%$ (3 patients) whereas high voltage injuries were 93.75\% (45 patients). In the study done by Kym D et al, low voltage injuries were $29.6 \%$ (185 patients), high voltage injuries were $70.4 \%$ (440 patients). In the study of Jiang M) et al,(6) high voltage injuries were 78.4\% (469/598 patients), arc burns were $8.7 \%(11 / 127$ patients). High voltage injuries were most common type causing compound defects.

In this study a total of 65 flaps were performed in 48 patients to cover defects. In the study by Eser et al,(7) 157 flaps in 117 patients were reported. In the study by Kym D et al.,(8) 711 flap surgeries in 362 patients were reported.

\section{Flaps on Scalp Defects}

In this study Scalp 11 defects were reconstructed. Eight (72.72\%) with Transposition flaps and the rest of defects were reconstructed with Rotation flap, Bipedicled flap, Trapezius musculocutaneous flap at one each $(0.91 \%)$ respectively. In study done by Eser $\mathrm{C}$ et al. Out of 21 flaps used to reconstruct scalp defects ten(47.62\%) were Scalp tissue flaps, one(4.76\%) was temporo-parietal fascia flap, one $(4.76 \%)$ was Trapezius musculocutaneous flap and seven (33.33\%) free flaps. In the study done by Kym D et al. out of 42 flaps most commonly done were Latissimus dorsi free flaps in $40.47 \%$ (17 patients), Transposition flaps were used in $16.67 \%$ (7 patients), Radial forearm free flaps were used in $7.14 \%$ (three patients), tissue expansion was used in $9.52 \%$ (4 patients) other procedures were used in $26.19 \%$ (11 patients). In the study done by Hossain MZ et al,(9) out of 30 patients, Rotation flaps were used in $40 \%$ (12 patients, among that eight patients $(26.67 \%)$ had single rotation flaps, four patients (13.33\%) had double opposing rotation flaps), followed by bipedicled flaps in $23.33 \%$ (seven patients), Transposition flaps in 10\% (three patients) Tissue expansion and primary closure was used in 3.33\% (One patient).

In all the studies compared most common flap used for scalp reconstruction was Transposition flap. Similarly, in this study transposition flap was used in $72.72 \%$ which correlates with studies of Eser C et al., Anjan B et al., could be due to the fact that it is a local flap with good colour tissue match and is easily executed. In the study of Kym D et al., most commonly reported flaps were free flaps, but in this study no free flaps were contemplated because of logistical issues. In the study of Hossain et al., Rotational flaps were commonly reported.

\section{Flaps on Facial Defects ${ }^{10}$}

In this study, one forehead defect was reconstructed with Rotation flap. One defect of lower eye lid was reconstructed with Fricke's flap. Two defects of nose were reconstructed with Median forehead flap with prior prelamination. One defect of upper lip was reconstructed with extracorporeal radial artery forearm flap. One defect of lower lip reconstructed with Deltopectoral flap. One patient with exposed mandible was difficult to manage. His chest region had burns so deltopectoral flap was not possible. He had to undergo multiple flaps for the same. Initially reconstructed with Trapezius musculocutaneous flap, has developed necrosis in critical area of the flap, then forehead flap was used to cover the critical area, this forehead flap also has developed necrosis at critical area, then pectoralis major musculocutaneous flap was used, it also has developed necrosis in critical area, then extra corporeal radial artery forearm flap was used along with tongue flap to cover intra oral aspect of mandible. This settled well without any complication. It was a learning experience; nutritional deficiency could be one of the prime causes for failure of flaps.

Recent study on reconstructive management of devastating electrical injuries to face done by Jeffrey E J et al.(10) Reported a retrospective case series of five patients reported where all cases were managed by early debridement and definitive flap cover by free flaps. Out of 
that two patients had facial transplantation. Now it has become debate whether to follow reconstructive ladder in facial electrical burns injuries or not. In this study reconstructive ladder is followed, mostly local flaps were used, followed by regional flaps, then distant flaps used and no free flaps used.

\section{Flaps on Upper Limb Defects}

In this study upper limb defects were reconstructed with various flaps depending upon the site of defect and possible tissues available. In this study Shoulder defects were reconstructed with Trapezius musculocutaneous flaps in 5.40 $\%$ (2 flaps out of 37 flaps).One Axilla defect was reconstructed with pedicled Latissimus dorsi musculocutaneous flap (2.70\%). Forearm and wrist defects were reconstructed with distant flaps like abdominal and groin flaps. Out of that most commonly used flaps were superiorly based abdominal flaps and Paraumbilical flaps each in 11 flaps out of 37 flaps (29.72\%), followed by inferiorly based abdominal flaps in five flaps (13.51\%) and groin flap in one instance $(2.70 \%)$. Defects of dorsum of hand were reconstructed with groin flaps in three patients (8.11\%). Fingers defects were reconstructed with Louvre flaps in two patients (5.40\%), Superiorly based abdominal flap in one patient $(2.70 \%)$. In the study done by Eser $\mathrm{C}$ et al, out of 103 flaps, most commonly used flaps were groin flaps $53.39 \%$ (55 flaps) followed by pedicled Latissimus dorsi muscle/ musculocutaneous flaps in $16.50 \%$ (17 flaps), local fasciocutaneous flaps in $14.56 \%$ (15 flaps), sub-mammerial flaps in $4.85 \%$ (5 flaps), cross finger flaps in $1.94 \%$ (2 flaps), Reverse Dorsal Metacarpal Artery flap in $1.94 \%$ (2 flaps), adipofascial turnover flaps in $2.91 \%$ (3 flaps), Superficial External Pudendal Artery flaps in $0.97 \%$ (one flap) and free Latissimus dorsi muscle flaps in $1.94 \%$ (2 flaps). In the study done by Kym D et al.(7) Out of 434 flaps most commonly used flaps were Groin flaps in 32.45\% (229 flaps) followed by Abdominal flaps in 20.2\% (115 flaps), Posterior interosseous artery flaps in 5.99\%(26 flaps), Cross finger flaps in $6.91 \%$ (30 flaps), Transposition flaps in $0.92 \%$ (4 flaps), Free flaps in $1.61 \%$ (7 flaps) and other flaps in $5.29 \%$ (23 flaps). In the study done by Segu SS et al,(11) Out of 110 flaps to cover upper limb defects 60 (54.55\%) flaps were Groin flaps, 28 (25.45\%) flaps were random Abdominal flaps, 15(13.64\%) flaps were Paraumbilical flaps, 4 (3.64\%) were Transposition flaps, $2(1.82 \%)$ flaps pedicled Latissimus dorsi flaps and one $(0.91 \%)$ fillet flap. In the study done by Sanjay KG et al,(12) Out of 40 flaps to cover upper limb defects 25\% (10 flaps) were Groin flaps, $15 \%$ (6 flaps) were Abdominal flaps, $12.5 \%$ (5 flaps) were Cross finger flaps, $12.5 \%$ (5 flaps) were free Anterolateral thigh flaps, $12.5 \%$ (5 flaps) were Reverse Radial Forearm flaps, $12.5 \%$ (5 flaps) were First dorsal metacarpal artery flaps and 10\% (4 flaps) were free Latissimus dorsi flaps.

\begin{tabular}{|c|c|c|c|c|c|}
\hline Study & $\begin{array}{c}\text { This } \\
\text { Study }\end{array}$ & $\begin{array}{c}\text { Eser C } \\
\text { et al }\end{array}$ & $\begin{array}{c}\text { Kym D } \\
\text { et al }\end{array}$ & $\begin{array}{c}\text { Segu SS } \\
\text { et al }\end{array}$ & $\begin{array}{c}\text { Sanjay } \\
\text { KJ et al }\end{array}$ \\
\hline Abdominal flap & $81.08 \%$ & $16.50 \%$ & $20.2 \%$ & $39.09 \%$ & $15 \%$ \\
\hline Groin flap & $10.81 \%$ & $53.59 \%$ & $32.45 \%$ & $54.5 \%$ & $25 \%$ \\
\hline Trapezius myocutaneous flap & $5.40 \%$ & 0 & 0 & 0 & 0 \\
\hline $\begin{array}{c}\text { Latissimus dorsi myocutaneous } \\
\text { flaps }\end{array}$ & $2.70 \%$ & $16.5 \%$ & 0 & $1.82 \%$ & 0 \\
\hline Free flaps & 0 & $1.94 \%$ & $1.61 \%$ & 0 & $35 \%$ \\
\hline Posterior interosseous artery flap & 0 & 0 & $5.99 \%$ & 0 & 0 \\
\hline Other flaps & 0 & $21.35 \%$ & $6.22 \%$ & $4.54 \%$ & $25 \%$ \\
\hline Table 10. Comparison Table for Upper Limb Flaps \\
\hline
\end{tabular}

In the study done by Shen YM et al. 98 flaps were used to reconstruct the wounds of electrical burns over wrist. Out of that 32 (32.65\%) flaps were groin flaps, $11.23 \%(11)$ flaps were Paraumbilical flaps, 9 (9.98\%) flaps were combined abdominal axial patterned flaps, 37 (37.75\%) were flaps free fasciocutaneous/musculocutaneous flaps, 3 (3.06\%) were flaps pedicled anterolateral thigh flaps and $6(6.12 \%)$ flaps were flow-through descending branch of lateral femoral circumflex artery flaps.

In this study most common site of compound defects was forearm and wrist, next was hand, fingers, shoulder and axilla in descending order of frequency. Common flap used in this study was abdominal flap followed by Groin flap, free flaps were not contemplated. For defects over shoulder Trapezius musculocutaneous flap done, for axilla defect Latissimus dorsi flap done. Similar studies reported Groin flap as the commonly used flap followed by abdominal flap and other flaps.

In abdominal flaps for reconstruction of forearm and wrist, most commonly used flaps were superiorly based abdominal flap and Paraumbilical flap followed by inferiorly based abdominal flap and groin flap. Local and Transpositional flaps were not preferred as vascular compromise might be more in electrical burn injuries in their vicinity which may pose a problem for flap survival.

For dorsum of hand, flap of choice could be Groin flap, for finger defects Louvre flap could be better option where local and regional tissues most commonly damaged.

\section{Flaps on Lower Limb Defects}

In this study, lower limb defects were reconstructed with Reverse sural artery flaps in $66.67 \%$ (four out of six flaps), followed by inferiorly based medial fasciocutaneous flap and cross leg flap in each $16.67 \%$ (one out of six) respectively.

In the study done by Eser $\mathrm{C}$ et al. Out of 30 flaps local fasciocutaneous flaps were used in $33.33 \%$ (10 flaps) followed by Reverse sural flaps in $30 \%$ ( 9 flaps), free Latissimus Dorsi flap in 16.67 \% (5 flaps), adipofascial flaps in $10 \%$ (3 flaps), Gastrocnemius muscle flap in 3.33\% (one flap), fascial flap, fasciocutaneous island flap in rest of cases. In the study done by Kym D et al. Out of 235 flaps Transposition flaps were used in $17.87 \%$ (42 flaps), Reverse sural island flaps were $13.91 \%$ (31 flaps), Latissimus dorsi free flaps were used in $27.65 \%$ (65 flaps), anterolateral thigh free flaps were used in $22.97 \%$ (54 flaps), radial forearm free flaps were used in $13.62 \%$ (32 flaps) and other flaps $4.68 \%$ (11 flaps).

\begin{tabular}{|c|c|c|c|}
\hline Study & This Study & Eser C et al & Kym D et al \\
\hline Reverse sural artery flap & $66.67 \%$ & $30 \%$ & $13.91 \%$ \\
\hline $\begin{array}{c}\text { Fasciculocutaneous } \\
\text { transposition flap }\end{array}$ & $16.67 \%$ & $33.33 \%$ & $17.87 \%$ \\
\hline Free latissimus dorsi flap & 0 & $16.67 \%$ & $27.65 \%$ \\
\hline Free anterolateral thigh flaps & 0 & 0 & $22.97 \%$ \\
\hline Free radial forearm flap & 0 & 0 & $3.62 \%$ \\
\hline Other flaps & $16.67 \%$ & $20 \%$ & $4.68 \%$ \\
\hline \multicolumn{4}{|c|}{ Table 11. Comparison of Lower Limb Flaps } \\
\hline
\end{tabular}

In this study for the lower limbs were able to perform mostly local fasciocutaneous flaps as transposition flap, followed by turnover flaps like Reverse sural artery flap for defects in and around leg and ankle were used. Next common flaps were free flaps depending upon size of defect and possible tissue available. These findings were correlate with the studies of Eser C et al., Kym D et al. 


\section{Complications of Flaps}

In this study the common complication was marginal necrosis observed in ten flaps (15.38\%) managed with debridement and reinset. Dehiscence of flap was noted in Eight flaps $(12.31 \%)$ which was managed with reinset of flap, hematoma in Two flaps $(3.08 \%)$ was managed with evacuation, Total flap necrosis occurred in Two flaps (3.08\%) which were managed with debridement and return of flap and other treatment options followed, Graft loss occurred in Three flaps(4.62\%)which were managed with skin grafting. Total $38.46 \%$ flaps had complications.

In study done by Eser $\mathrm{C}$ et al, common complication was marginal necrosis in $12.2 \%$ (19) cases which were managed with debridement and reinset, 3.85\% (six) cases of infection were managed with debridement, local and parenteral antimicrobial therapy as per wound cultures and antibiograms. In $0.64 \%$ (one) case hematoma under the flap was noted and was managed by evacuation, three cases of total free flap (18.8\%) loss in sixteen free flaps observed.

\section{CONCLUSIONS}

Majority of the study population was male $91.67 \%$ while $8.33 \%$ was female. The age of patients ranged between 9 to 60 years, with 21-30 years being the most common affected age group. Most of the patients with defect underwent delayed flap cover (95.38\%) while $4.62 \%$ underwent early flap coverage. Most common site involved in electrical burns was forearm and wrist (45.90\%). For defects over forearm and wrist, most commonly used flaps were superiorly based fasciocutaneous flaps and paraumbilical flaps equally with $29.73 \%$ each. Most common flaps for scalp defects were transposition flaps $72.73 \%$, for shoulder reconstruction was trapezius musculocutaneous flap (100\%), for leg and ankle was reverse sural artery flap $66.67 \%$. Average duration of hospital stay was 60.54 Days. Complications occurred in $38.46 \%$ (25 out of 65 ) flaps with commonest complication being marginal necrosis which occurred in $15.38 \%$. Based on observations of this study further research may be contemplated according to individual regions like scalp, face, upper limb, lower limb, perineum and trunk and with early debridement, early flap coverage and to assess the standard different management options including newer methods.

\section{REFERENCES}

[1] Esses SI, Peters WJ. Electrical burns: pathophysiology and complications. Can J Surg1981;24(1):11-4.

[2] Wolfe SW, Hotchkiss RN, Pederson WC, et al. Greens Operative Hand Surgery. Chapter - 63. The burned hand, electrical Injury. Vol. I. $6^{\text {th }}$ edn. Churchill Livingstone 1982.

[3] Cushing TA, Alcock J. Electrical injuries in emergency medicine. Clinical presentation (article). 2018;13:82-6.

[4] Edlich RF, Vistnes LM. Electrical Burn Injuries (article). 2017;11:54-8.

[5] Knox KR, Morin RJ, Fleegler EJ. Electrical burn of the upper extremity. In: Hunt JL, edr. Critical management and soft tissue pattern in acute Electrical burn injury. Cambridge University Press 1992.

[6] Jiang MJ, Li Z, Xie WG. Epidemiological investigation on 2133 hospitalized patients with electrical burns. Zhonguhua Shao Shang ZA Zhi 2017;33(12):732-7.

[7] Eser C, Kesiktas E, Gencel E, et al. Algorithms of flap reconstruction in high-voltage electrical injuries: 26 years of experience. Trauma Cases \& Reviews 2015;1:1.

[8] Kym D, Seo DK, Hur GY, et al. Epidemiology of electrical injury: differences between low- and high-voltage electrical injuries during a 7-year study period in South Korea. Scandinavian Journal of Surgery 2014;104(2):108-14.

[9] Hossain MZ, Sarker B, Lenin LK, et al. Scalp Reconstruction following high voltage electric burn. BJPS 2012;3(2):49-52.

[10] Jeffrey EJ, Ibrahim K, Craig RL, et al. Reconstructive management of devastating electrical injuries to the face. Plast Reconstr Surg 2015;136(4):839-47.

[11] Segu SS, Jaganathan V, Biradar AV, et al. A review of 5 years of experience in management of electrical injuries. Indian J Burns 2014;22:104-8.

[12] Sanjay KG, Satyajit S, Arpan H, et al. Reconstruction of post electric burn defects of upper limb with different modification of flaps. International Journal of Medical and Health Research 2018;4(7):36-9. 